\title{
Sensitivity of hydrodynamic parameters in the simulation of water transfer processes in a permeable pavement
}

\author{
Sensibilidade dos parâmetros hidrodinâmicos na simulação dos processos de transferência de \\ água em um pavimento permeável
}

\author{
Ialy Rayane de Aguiar $\operatorname{Costa}^{1}$ (D), Artur Paiva Coutinho ${ }^{2}$ (D), Suzana Maria Gico Lima Montenegro ${ }^{1}$ (D), \\ Ana Emília Carvalho de Gusmão da Cunha Rabelo ${ }^{1}$ (D), Severino Martins dos Santos Neto ${ }^{1}$ (D), Edevaldo Miguel Alves ${ }^{2}$ \\ \& Antonio Celso Dantas Antonino ${ }^{1}$ (D) \\ ${ }^{1}$ Universidade Federal de Pernambuco, Recife, PE, Brasil \\ ${ }^{2}$ Universidade Federal de Pernambuco, Caruaru, PE, Brasil \\ E-mails: ialyraguiarc@gmail.com (IRAC), arthur.coutinho@yahoo.com.br(APC), suzanam@ufpe.br (SMGLM), anaerabelo@gmail.com
} (AECGCR), martinsdsn@gmail.com (SMSN), edevaldofisica@gmail.com (EMA), antonio.antonino@ufpe.br (ACDA)

Received: December 21, 2019 - Revised: July 24, 2020 - Accepted: August 11, 2020

\begin{abstract}
The high urbanization process has caused profound changes in the components of the hydrological cycle, causing various problems such as flooding, rainwater degradation, among others. Low Impact Development (LID) techniques have proven to be a viable and effective alternative to stormwater management, reducing runoff, and increasing the infiltration and evapotranspiration capacity of urban areas. The operation prediction of a compensatory technique, such as permeable pavement, depends on the hydrodynamic properties of the permeable pavement layers and the subsoil properties. The numerical solutions based on the solution of Richards' equation have been the most used to estimate water transfer processes. The objective of this work was to investigate the influence of hydrodynamic parameters on the hydraulic behavior of a permeable pavement installed in Recife-PE. The effect of 5 hydrodynamical parameters was analyzed for a highly heterogeneous permeable pavement. The Hydrus 1-D model was used to simulate water transfer processes on the permeable pavement. Initially, a sensitivity analysis of the mesh refinement degree was performed to simulate the transfer processes in the permeable pavement. The response surface method was applied to the hydrodynamic parameters to perform the sensitivity analysis. The calculations were carried out for hourly and daily time scales. As a result, it was observed that the spatial discretization had no influence on the scenarios of the flow variable. The use of a daily time resolution reduced the influence of events with higher precipitation intensity, underestimating the generation of runoff. The surface runoff showed higher sensitivity to the parameters of the superficial layer, especially to the saturated hydraulic conductivity. The cumulative infiltration and groundwater recharge showed low sensitivity when the hydrodynamic parameters of the retention curve and the saturated hydraulic conductivity varied. The volume of water stored in the profile showed higher sensitivity to the ' $\theta \mathrm{s}$ ' and ' $\mathrm{n}$ ' parameter of the subbase layer. The use of meteorological input data with different temporal resolutions for the simulation of the water transfer processes in the permeable pavement section demonstrated that the hydrodynamic parameters have a higher influence than the climatic variables in the daily resolution. The use of meteorological data with hourly temporal resolution demonstrated that runoff was hypothetically controlled by meteorological variables. The mesh and parameter sensitivity analysis can influence researches that seek to understand water transfer processes in a structure as a permeable pavement through the Richards' equation, generating a lower operating cost and speeding up simulations.
\end{abstract}

Keywords: LID; Richards' equation; Numerical errors; Hydrus.

\section{RESUMO}

O elevado processo de urbanização tem provocado profundas alterações nos componentes do ciclo hidrológico, ocasionando diversos problemas como inundações, degradação das águas pluviais, entre outros. As técnicas de Desenvolvimento de Baixo Impacto (LID) provaram ser uma alternativa viável e eficaz na gestão das águas pluviais, reduzindo o escoamento superficial e aumentando a capacidade de infiltração e evapotranspiração das áreas urbanas. A previsão do funcionamento de uma técnica compensatória como um pavimento 
permeável depende das propriedades hidrodinâmicas das camadas do pavimento permeável, bem como das propriedades hidráulicas do subsolo. Os modelos baseados na solução numérica da equação de Richards têm sido os mais utilizados para a estimativa dos processos de transferência de água. O objetivo deste trabalho foi investigar a influência dos parâmetros hidrodinâmicos no comportamento hidráulico de um pavimento permeável instalado na cidade de Recife-PE. O efeito de 5 parâmetros hidrodinâmicos foi analisado para um pavimento permeável altamente heterogêneo. Foi utilizado o modelo Hydrus 1-D para simular os processos de transferência de água num pavimento permeável. Inicialmente foi realizada uma análise de sensibilidade do grau de refinamento da malha para simulação dos processos de transferência no pavimento permeável. O método de superfície de resposta foi aplicado para a análise de sensibilidade aos parâmetros hidrodinâmicos. As estimativas foram realizadas para as escalas de tempo diária e horária. Como resultados, observou-se que a discretização espacial não exerceu influência nos cenários das variáveis de fluxo. O uso de uma escala de tempo diária diminuiu a influência dos eventos de maior intensidade de precipitação, subestimando a geração de escoamento superficial. A lâmina escoada apresentou maior sensibilidade aos parâmetros da camada superficial, principalmente à condutividade hidráulica saturada. A infiltração e recarga acumuladas apresentaram baixa sensibilidade à variação dos parâmetros. A estimativa da lâmina armazenada no perfil foi mais sensível aos parâmetros ' $\theta$ s' e 'n' da camada de subbase. A utilização de dados de entrada climatológicos com diferentes resoluções temporais para a simulação dos processos de transferência de água na seção do pavimento permeável demonstrou que na resolução diária os parâmetros hidrodinâmicos apresentam maior influência que as variáveis climáticas. A utilizados de dados climatológicos com resolução temporal horária demonstrou que o escoamento superficial foi hipoteticamente controlado pelas variáveis meteorológicas. A análise de sensibilidade da malha e dos parâmetros pode influenciar pesquisas que busquem entender os processos de transferência de água em uma estrutura como um pavimento permeável através da equação de Richards, gerando um menor custo operacional e dando celeridade às simulações.

Palavras-chave: LID; Equação de Richards; Erros numéricos; Hydrus.

\section{INTRODUCTION}

The high urbanization process leads to the imbalance of the hydrological cycle components. Increased runoff, decreased evapotranspiration, infiltration, and natural recharge of aquifers are the main consequences of the intense surface impermeabilization process (Liu et al., 2019). In this context, there is an unwanted occurrence of urban problems such as flooding, temperature increase, rainwater degradation, among others (Oleson et al., 2015; St-Hilaire et al., 2016). In face of that, the management of stormwater with the use of nature-based technologies is an essential instrument in controlling runoff in urban areas and favoring natural phenomena such as infiltration and urban rainwater storage.

To reestablish the natural conditions of urban water transfer processes, new practices based on water infiltration and storage have emerged, which minimize the impacts of urbanization. Besides that, they promote a reduction of direct runoff volume and water pollution and favor the quantitative recharge of groundwater. These practices constitute an approach known as Low Impact Development (LID), which is a green approach to stormwater management and has been increasingly used in urban drainage. To achieve their goals, LID technologies depend mainly on infiltration and evapotranspiration and seek to incorporate natural processes into their functioning. These techniques, also called compensatory techniques, consist of bioretention cells, infiltration trenches, infiltration ditches, permeable pavements, green roofs, rain gardens, water catchment systems, and others (Eckart et al., 2017). Several studies have confirmed the quantitative and qualitative benefits of LIDs in the hydrological cycle (Coutinho et al., 2015, 2016; Melo et al., 2016). Permeable pavements are remarkably effective in terms of runoff reduction, retention and water quality (Kamali et al., 2017; Braswell et al., 2018).

Permeable pavements are used to mitigate the adverse effects of urban stormwater runoff, such as increased runoff volume and deterioration of receiving water quality. Permeable paving can be used as an alternative to conventional surfaces such as roads, public roads, parking lots and sidewalks (Jabur et al., 2015; Bruno et al., 2013).

The knowledge of how a compensatory technique such as permeable pavement works by promoting infiltration, groundwater recharge, and evapotranspiration depends on the hydrodynamic properties of the permeable pavement components and the hydrodynamic properties of the subsoil. Models based on Richards' equation numerical solution are the most used to estimate soil water transfer processes (Coutinho et al., 2015, 2016; Brunetti et al., 2016). They are based on the simultaneous soil water retention and conduction properties, expressed by the retention curves and hydraulic conductivity curves, respectively.

In these terms, the estimation of water transfer processes in a heterogeneous infiltration technique such as a permeable pavement presents high complexity. This complexity occurs due to the high nonlinearity of the retention and conductivity curves, combined with the diversity of the permeable pavement constituent layers: coating, sand filter layers, reservoir, and subbase layers. These have a high disparity of hydraulic properties, which are mainly observed in porosity, hydraulic conductivity, and operating contrast in unsaturated conditions.

Therefore, sensitivity analysis is a fundamental alternative for understanding the individual contribution of each hydrodynamic parameter and pavement layer in the hydrological processes (Brunetti et al., 2018). The results of this analysis will guide research to estimate a given parameter with greater precision. They will also provide researchers with knowledge of which parameter should be placed as a decision variable in model calibration and validation periods, or when the inverse method should be used (Silva Ursulino et al., 2019). Consequently, more rigorous criteria are used to estimate the parameters, increasing the model's accuracy.

In addition, the simulation of hydrological processes such as surface runoff, water infiltration and groundwater recharge in compensatory techniques is related to the time resolution of 
meteorological data and the hydrodynamic properties of the porous medium, which can interfere in the accuracy of the estimations.

Models that describe water flow under saturated and unsaturated conditions such as Hydrus have been widely used to estimate water flows in compensatory techniques. In particular, the use of the Hydrus model in structures such as permeable pavement has resulted in successful applications in various works. One of these is the study by Coutinho et al. (2016), who evaluated the influence of the hydrological behavior of different textures used as filler material on a permeable pavement such as interlocking blocks in the city of Recife. Graciosa et al. (2008) performed a hydraulic simulation of a rainwater infiltration trench using the BIDISUL model, based on the Richards equation. The authors observed that the model underestimated the infiltrated volumes, attributing the uncertainties of the retention curve to the observed differences.

Brunetti et al. (2016) performed a baseflow sensitivity analysis on a permeable pavement to the parameters of the retention curve using the Hydrus 1D model. These authors observed that the retention curve shape parameter and the air inlet pressure parameter in the coating layer were the properties that most influenced the hydraulic performance of the permeable pavement.

In this context, the present work aims to evaluate the influence of uncertainties of the hydrodynamic parameters on water transfer processes (infiltration, evapotranspiration, water storage, and groundwater recharge) in several layers of a permeable pavement using the Hydrus 1D model.

\section{MATERIAL AND METHODS}

\section{Study area}

The permeable pavement described in this work is located in the parking lot of the Center of Technology and Geosciences of the Federal University of Pernambuco (UFPE), in the city of Recife/PE, at coordinates 8 ${ }^{\circ} 03^{\prime} 09.7^{\prime}$ 'S and 3457'15.7'W, approximately 4 meters above sea level (Figure 1). According to the Köppen classification, the climate in the region is As' (hot and humid), with a rainy season in the winter period, with higher precipitation from March to August, when approximately $70 \%$ of the total annual rainfall occurs.

The pilot permeable pavement has a surface area of $4.5 \mathrm{~m}^{2}$ and was built to drain a parking area of $110 \mathrm{~m}^{2}$. In the coating layer, there are concrete grid pavers (CGP) with internal voids filled with soil and grass. The sand layer acts as a filter and the reservoir layer consisting of gravel with an average diameter of $19 \mathrm{~mm}$ and $43 \%$ porosity. The gravel layer acts by temporarily storing the infiltrated water. Below the gravel layer, there is a sand layer. The subbase is composed of urban soil that was already present in the site and acts as a natural mouth for the stored water. Geotextile layers of $1 \mathrm{~cm}$ were arranged between the reservoir and the upper and lower sand layers to prevent fine particles from being dragged to the other layers. Figure 2 shows a schema of the permeable pavement structure.

\section{One-dimensional numerical modeling}

For the simulations, it is considered that during rainfall events, concrete elements do not infiltrate water and route runoff water to the closest soil elements. During dry weather, evapotranspiration occurs essentially over soil elements.

The simulation of the water dynamics in the permeable pavement was performed with the support of the HYDRUS-1D Software (Šimůnek \& Van Genuchten, 2008). Hydrus1-D is a computer program that simulates water dynamics in saturated and unsaturated soils, whether cultivated or not, applying the solution of Richards' (1931) equation (Equation 1), using finite elements.
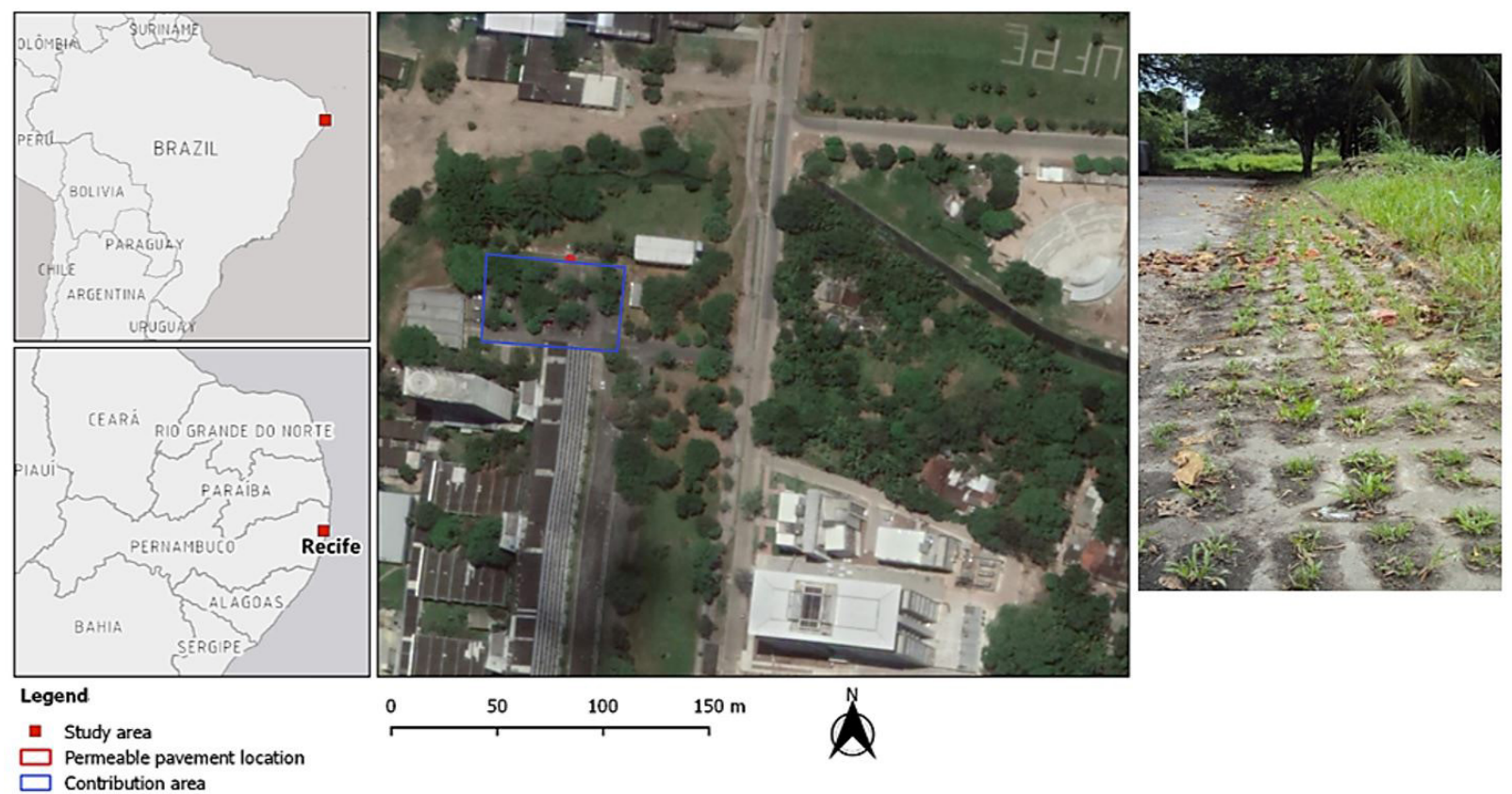

Figure 1. Location of the permeable pavement at the experimental site of the Federal University of Pernambuco. 


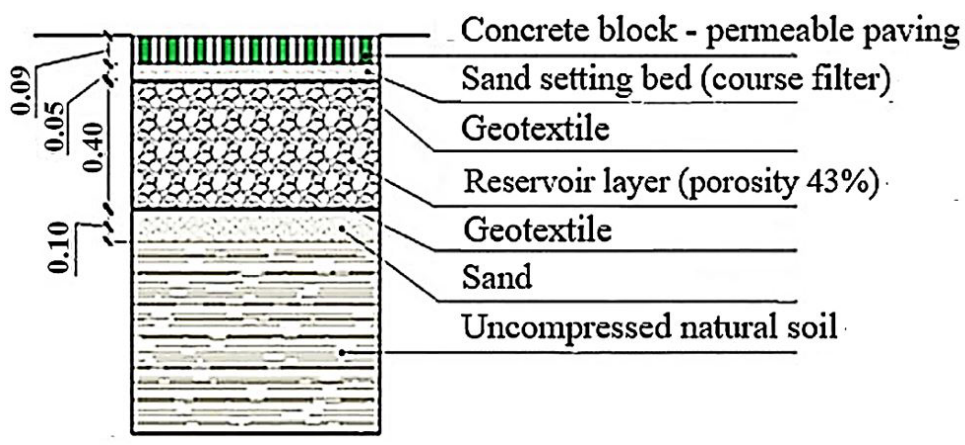

Figure 2. Scheme of the pilot permeable pavement structure (dimensions in m). Source: Coutinho et al. (2016).

$$
\frac{\partial \theta}{\partial t}=\frac{\partial}{\partial x}\left[K(h)\left(\frac{\partial h}{\partial x}+\cos \alpha\right)\right]-S
$$

where $\mathrm{h}$ is the matrix potential of water in the soil, $\mathrm{L} ; \theta$ is the volumetric moisture of water, $\mathrm{L}^{3} \mathrm{~L}^{-3}$; $t$ is the time, $\mathrm{T}$; $\mathrm{x}$ is the spatial coordinate, $\mathrm{L} ; \mathrm{S}$ is a sink term, $\mathrm{L}^{3} \mathrm{~L}^{-3} \mathrm{~T}^{-1}$; $\alpha$ is the angle between the flow direction and the vertical axis, i.e., $\alpha=0^{\circ}$ for vertical flow, $90^{\circ}$ for horizontal flow and $0^{\circ}<\alpha<90^{\circ}$ for inclined flow.

The hydraulic properties of unsaturated soil, $\theta(\mathrm{h})$, and $\mathrm{K}$ (h) are generally nonlinear functions of the matrix potential or volumetric moisture. In these simulations, $\theta(h)$ and $K(h)$ were described by van Genuchten's model (1980) with the pore distribution hypothesis of Mualem (1976). The equations are given in (2), (3), (4) and (5), where $\theta \mathrm{r}$ and $\theta \mathrm{s}$ are the residual and saturated soil water content $\left[\mathrm{L}^{3} \mathrm{~L}^{-3}\right]$, respectively, $\mathrm{Ks}$ is the saturated hydraulic conductivity $\left[\mathrm{LT}^{-1}\right], \mathrm{n}$ is a pore size distribution parameter $[-], \alpha$ is the inverse of the air-entry pressure $\left[\mathrm{L}^{-1}\right], 1$ indicates tortuosity and is generally assumed to be 0.5 for many soils and Se is the degree of effective saturation.

$\theta(h)= \begin{cases}\theta_{r}+\frac{\theta_{s}-\theta_{r}}{\left[1-(\alpha|h|)^{n}\right]^{m}} & \text { if } h \leq 0 \\ \theta_{s} & \text { if } h>0\end{cases}$

$m=1-\frac{1}{n}$

$S_{e}=\frac{\theta(h)-\theta_{r}}{\theta_{s}-\theta_{r}}$

$K(h)= \begin{cases}K_{s} S_{e} l\left[1-\left(1-S_{e}{ }^{l / m}\right)^{m}\right]^{2} & \text { if } h \leq 0 \\ K_{s} & \text { if } h>0\end{cases}$

Coutinho et al. (2016) performed the hydraulic characterization of the soil covering layer applying the BEERKAN method (Braud et al., 2005; Lassabatère et al., 2006), using the BEST algorithm, in which four main soil types were detected: silt, sandy silt, silty sand, and sand. In this study, was considered the sand fraction. The BEST is based on the use of Van Genuchten's (1980) relationship to the water retention curve with Burdine's (1953) condition. Therefore, the Retention Curve code (RETC) (Van Genuchten et al., 1991) was used to obtain the retention curve parameters considering Mualem (1976) hypothesis. The hydrodynamic properties of the subbase layer were estimated in Hydrus using Rosetta software (Coutinho, 2011), based on its particle size data analysis. For the sand layers were used the properties available in the Hydrus catalog, which is based on values reported by Carsel \& Parrish (1988). Regarding the reservoir layer, Hydrus-1D software does not offer the possibility of using gravel or any other material with a particle diameter larger than coarse sand. To overcome this deficiency, it was used in the program a sand layer with porosity equal to the gravel in the experiment. The hydrodynamic parameters for each layer are presented in Table 1.

The numerical domain representing the permeable pavement structure was divided into five layers, which are the constituent layers of the pavement, considering the subbase with 3 meters depth (Figure 3). The atmospheric condition was established as the water flow boundary condition for the upper limit, considering that the permeable pavement is required by rainfall and evapotranspiration. Meanwhile, free drainage condition was considered for the lower limit of the profile. The simulations were performed with daily and hourly meteorological data for a period of one year to investigate effects on the estimation of output variables. The time discretization was designed to facilitate the numerical convergence and calculation, with an initial time step of $10^{-5}$ hours, a minimum time step $10^{-8}$ hours, and a maximum time step not exceeding 0.01 hours for hourly resolution data. For daily resolution data the initial time step was of $4.17 \times 10^{-7}$ days, a minimum time step $4.17 \times 10^{-10}$ days, and a maximum time step not exceeding $4.17 \times 10^{-4}$ days. Meteorological data were downloaded from the Brazilian National Institute of Meteorology (Instituto Nacional de Meteorologia, 2020) database, considering the period from july/19 to july/2020 of the station A301. The data included hourly precipitation ( $\mathrm{mm})$, maximum and minimum temperatures $\left({ }^{\circ} \mathrm{C}\right)$, wind speed $\left(\mathrm{km} \mathrm{h}^{-1}\right)$ at $200 \mathrm{~cm}$ above the land surface, air humidity (\%) and solar radiation. The reference evapotranspiration was calculated using the Penman-Monteith equation (Allen et al., 1998).

For a rainfall event, it is considered that the contributing flows from parking are routed to the permeable pavement. Thus, the fluxes imposed on the pavement can be derived from mass balance consideration as follows:

$$
i_{p p}=P\left(1+\frac{A_{p a r k} C}{A p p}\right)
$$


Table 1. Hydrodynamic parameters of the permeable pavement layers.

\begin{tabular}{cccccc}
\hline Layer & $\boldsymbol{\theta}_{\mathbf{r}}\left[\mathbf{c m}^{3} / \mathbf{c m}^{3}\right]$ & $\boldsymbol{\theta}_{\mathbf{s}}\left[\mathbf{c m}^{3} / \mathbf{c m}^{3}\right]$ & $\boldsymbol{\alpha}[\mathbf{1} / \mathbf{c m}]$ & $\mathbf{n}[-]$ & $\mathbf{K}_{\mathbf{s}}[\mathbf{c m} / \mathbf{d a y}]$ \\
\hline 1 - Coating & 0.008 & 0.510 & 0.111 & 1.748 & 138.000 \\
2 - Sand & 0.045 & 0.430 & 0.145 & 2.680 & 712.800 \\
3 - Reservoir & 0.045 & 0.430 & 0.145 & 2.680 & 712.800 \\
4 - Sand & 0.045 & 0.430 & 0.145 & 2.680 & 712.800 \\
5 - Subbase & 0.054 & 0.531 & 0.030 & 1.424 & 239.200 \\
\hline
\end{tabular}

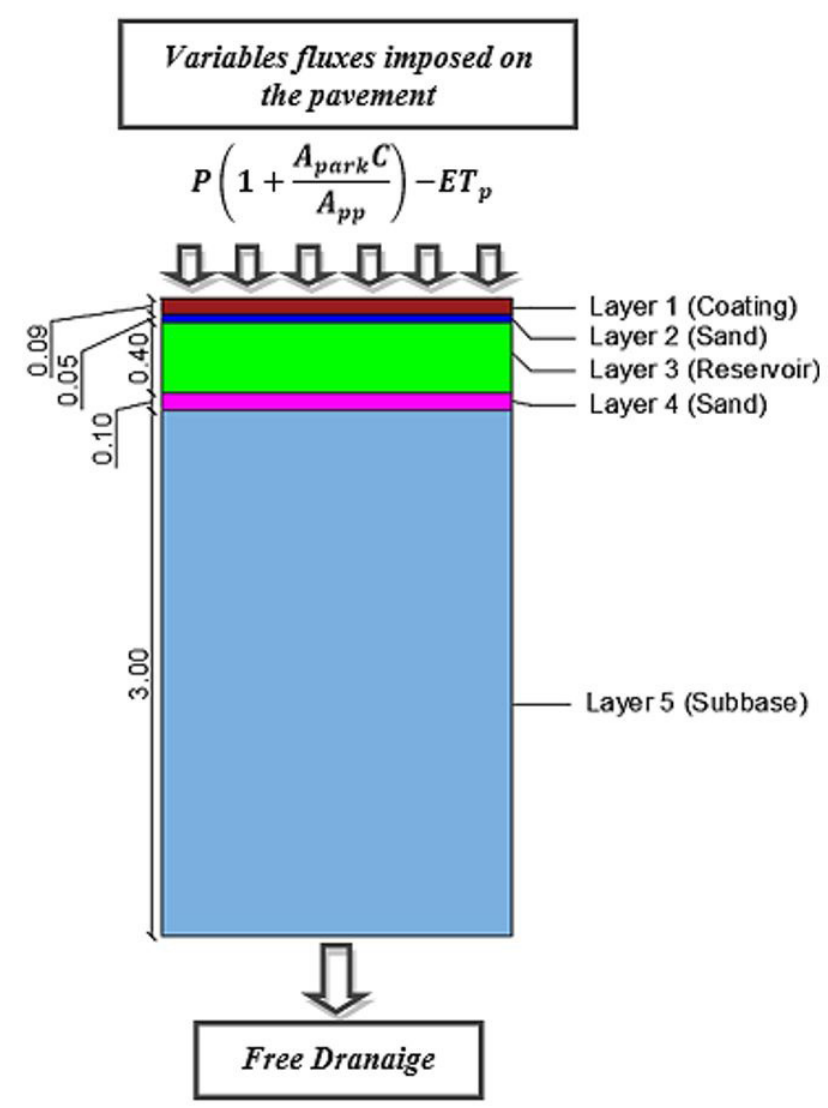

Figure 3. Numerical domain representing the permeable pavement structure in Hydrus-1D and boundary conditions.

where $\mathrm{i}_{\mathrm{pp}}$ is the flux imposed to the permeable pavement, $\mathrm{P}$ is rainfall intensity at time interval, $A_{\text {park }}$ is the parking area $\left(110 \mathrm{~m}^{2}\right), \mathrm{C}$ is parking runoff coefficient, considered $0.85, \mathrm{~A}_{\mathrm{pp}}$ is the permeable pavement area. The hourly precipitation, calculated potential evaporation rates and cumulative flux series are presented in Figure 4.

Initial conditions were specified in terms of water pressure in the soil. For each layer was adopted an initial condition equal to its field capacity (Figure 5).

\section{Sensitivity analysis of the mesh refinement}

Several studies have shown that mechanistic models can provide a rigorous description of water transfer processes in compensatory techniques. However, to increase the model reliability and its ability to describe real-world processes, it is necessary to perform simulations of model calibration, sensitivity analysis, and uncertainty quantification. These processes require running the model hundreds or thousands of times, demanding a high computational cost (Brunetti et al., 2017).

Aiming to reduce the computational cost in these simulations, a sensitivity analysis of the profile mesh was performed to verify the effects of its refinement on flow estimations in the pavement. Therefore, meshes of 101, 201, 301, 401, 501 and 601 nodes uniformly distributed throughout the numerical domain were analyzed. It was verified their influence on the estimation of the cumulative groundwater recharge, cumulative runoff, average water storage, cumulative actual evapotranspiration, and cumulative infiltration. To achieve this, the simulations were performed with the respective meshes, and the accumulated variables estimated by each simulation were compared, aiming to identify if there was a discrepancy in the numerical solutions for the more refined mesh (601 nodes). In the absence of significant differences, the less refined mesh is used to speed up the simulations.

\section{Sensitivity analysis of hydrodynamic parameters}

The sensitivity analysis of the hydrodynamic parameters was performed using the response surface method, where several simulations are performed by modifying only one parameter at a time, while the others are kept fixed (Alves et al., 2012; Gabiri et al., 2018). In this study was investigated the influence of the inverse capillary length $(\alpha)$, pore size distribution parameter $(n)$, saturated hydraulic conductivity $(\mathrm{Ks})$, saturated soil water content $(\theta \mathrm{s})$ and residual soil water content $(\theta \mathrm{r})$ for the same flow variables evaluated in the mesh sensitivity. Each parameter varied by $-50,-40,-30$, $-20,-10,+10,+20,+30,+40$ and +50 in percentage from the values defined in Table 1.

The $\mathrm{n}$ parameter does not assume values below the unit. Then, it was not possible to perform all variations for this parameter in the coating and subbase layers. Therefore, the smallest variations were -40 and $-20 \%$ for these layers, respectively.

The sensitivity of the model was quantified by relative sensitivity. According to McCuen \& Snyder (1986), relative sensitivity $(\mathrm{Sr})$ is defined as the ratio between the variation rate of the model response $(\Delta \mathrm{O})$ to a small input variation $(\Delta \mathrm{F})$, normalized by the initial output $\left(\mathrm{O}_{0}\right)$ and input $\left(\mathrm{F}_{0}\right)$ values, respectively (Equation 7$)$.

$$
S_{r}=\frac{\Delta O / O_{0}}{\Delta F / F_{0}}
$$

According to Chaves (1991), the model presents high sensitivity to the parameter when $|\mathrm{Sr}|>1.5$; intermediate sensitivity to $0.5<|\mathrm{Sr}|<1.5$; and low sensitivity if $|\mathrm{Sr}|<0.5$. Values close to zero indicate that the model is relatively insensitive to the parameter (McCuen \& Snyder, 1986). The sensitivity analyzes were computed for hourly and daily temporal resolutions. 

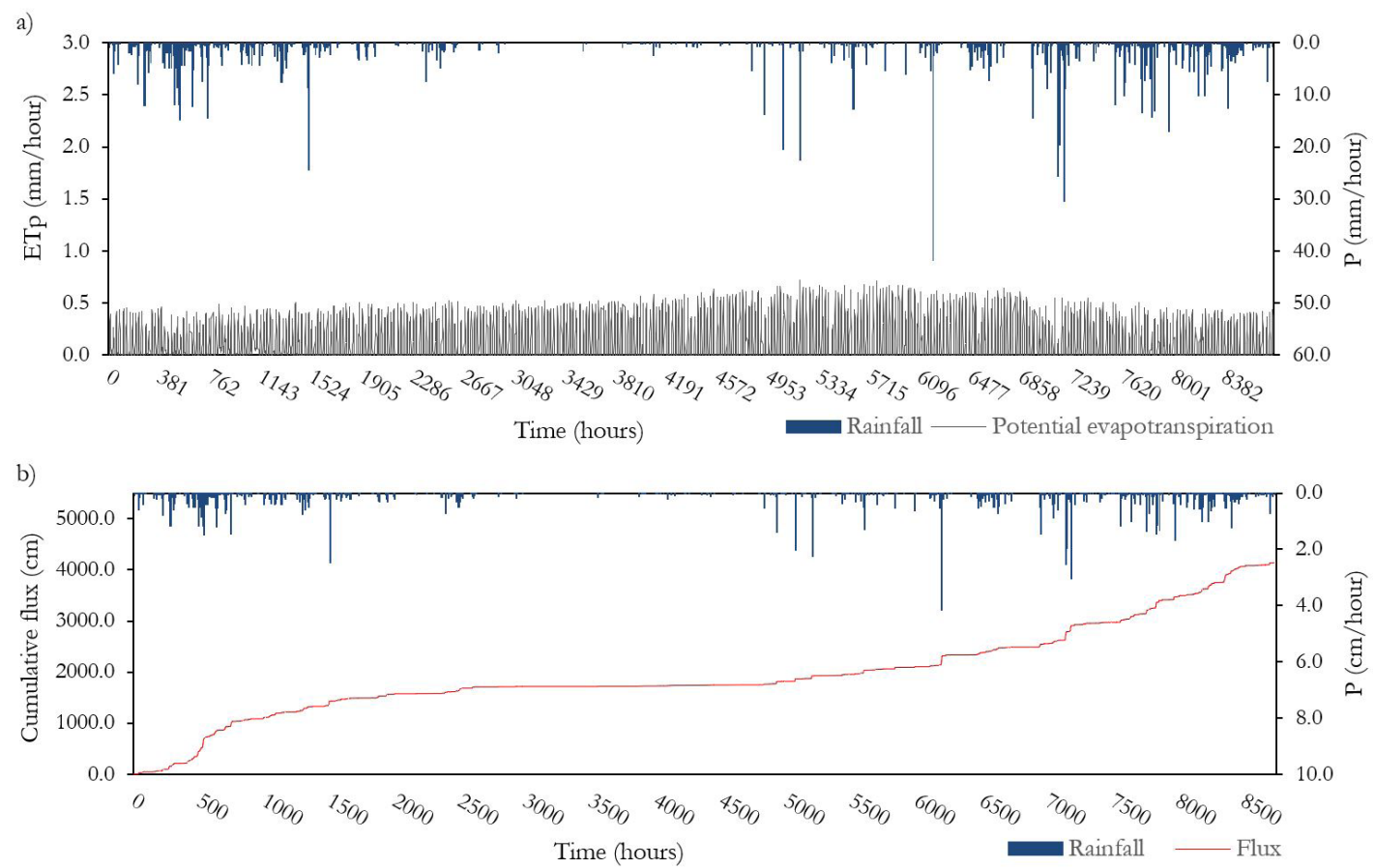

Figure 4. (a) Rainfall and potential evapotranspiration series and (b) Fluxes imposed on the permeable pavement used in the simulations.

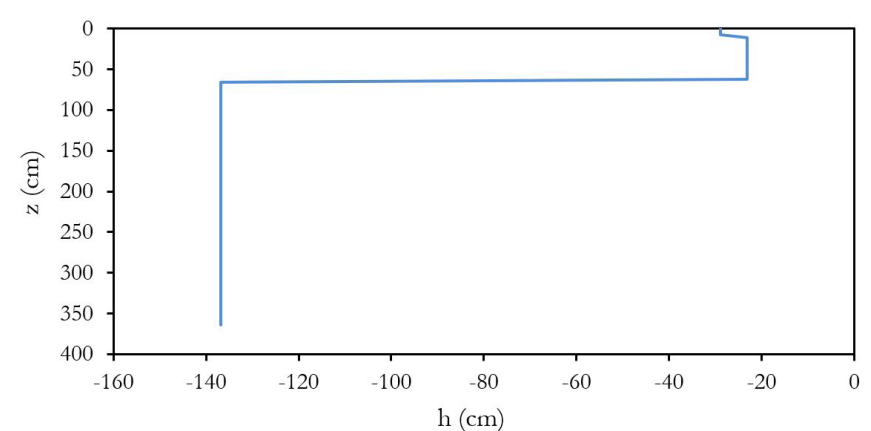

Figure 5. Initial condition of soil water matric potential.

\section{RESULTS AND DISCUSSION}

\section{Mesh sensitivity analysis}

Mesh sensitivity analysis is of fundamental importance to define the degree of refinement required to be used in the simulations. Therefore, it is possible to provide accurate scenarios of the soil hydraulic-hydrological behavior, and thus obtain representative results. The importance of this analysis is in the possibility of speeding up the simulations by choosing the less refined mesh if no significant influence of the mesh variation in the studied variables is observed. Figure 6 shows the sensitivity of each output variable to the number of nodes $(101,201,301,401$, 501 and 601) used in the profile with hourly input data. Although the results of the mesh sensitivity analysis in the daily resolution is not presented, in this resolution there was also a convergence in the variables estimated. It is observed that a refinement of the mesh by increasing its density did not change the dynamics of the surface runoff, the water infiltration, the groundwater recharge, and the average soil water storage. The actual evaporation presented alterations. However, the difference in behavior was negligible (less than 10\% compared to the more refined mesh). Overall, the behavior of the variables was shown to be independent of the spatial discretization degree.

The absence of differences in the flow variables dynamics allows simulations with the least dense mesh (101 nodes) because the increase in mesh density did not show significant accuracy gains in the estimation of the variables.

\section{Hourly versus daily simulation for the hydrological variables}

Figure 7 shows the curves for cumulative surface runoff, cumulative infiltration, cumulative actual evapotranspiration, cumulative groundwater recharge and average water storage obtained with simulations on hourly and daily time resolutions. In general, it is observed that the use of meteorological data on a daily resolution to the detriment of an hourly time series promotes an underestimation of surface runoff (Figure 7a), an overestimation of the cumulative infiltration (Figure $7 \mathrm{~b}$ ) and consequently greater water storage in the structure (Figure $7 \mathrm{e}$ ) and a greater recharge of the water table in the long term (Figure $7 \mathrm{~d}$ ).

The estimated surface runoff on daily resolution showed lower values than the ones presented for the hourly resolution all the time. The difference between the final cumulative surface runoff for daily and hourly simulations is $1425 \mathrm{~cm}$. In this context, the average runoff coefficient on the permeable pavement resulting from the simulation on the daily scale is approximately zero. However, on the hourly scale, the resulting coefficient is 0.36 , which implies values closer to those reported in the literature. 
Bruno et al. (2013) obtained a runoff coefficient of 0.23 for a rainfall intensity of $121 \mathrm{~mm} / \mathrm{h}$ on a permeable pavement lined with interlocking blocks. For this work, it is observed that for an event with an intensity of $41.8 \mathrm{~mm} / \mathrm{h}$, the estimated runoff coefficient is 0.83 . These results are in line with those observed by Tarqui et al. (2019), who obtained a runoff coefficient of 0.79 for a rainfall intensity of $21.9 \mathrm{~mm} / \mathrm{h}$ on a pavement with interlocking blocks in the city of Salvador/Bahia. This result demonstrates that the mechanisms for generating surface runoff can be better understood from greater detail on the time scale.

The use of a daily time resolution reduces the influence of events with higher precipitation intensity, underestimating the

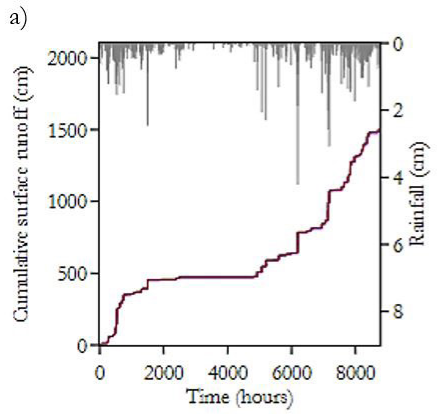

d)

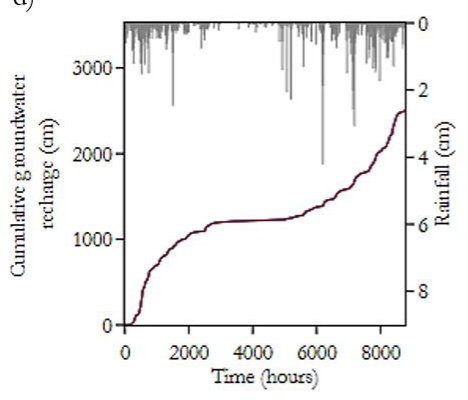

b)

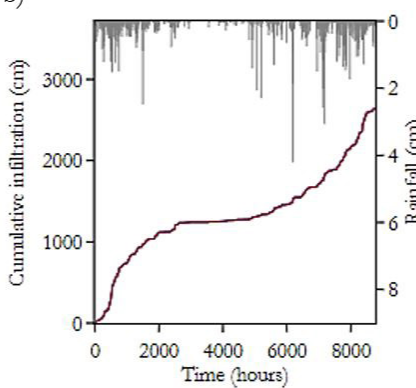

e)

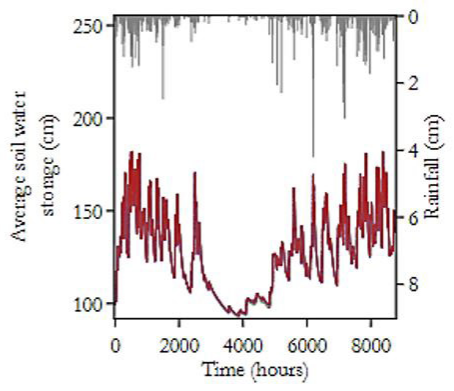

$-101-201-301-401$

$501-601$

Rainfall

Figure 6. Mesh sensitivity for the variables: (a) cumulative surface runoff; (b) cumulative infiltration; (c) cumulative actual evapotranspiration; (d) cumulative groundwater recharge; and (e) average soil water storage.

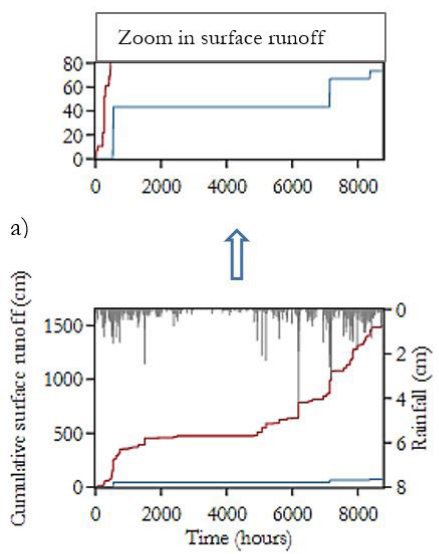

d) b)

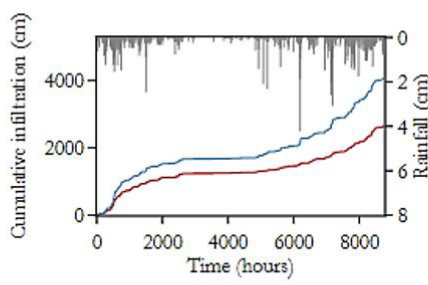

e) c)

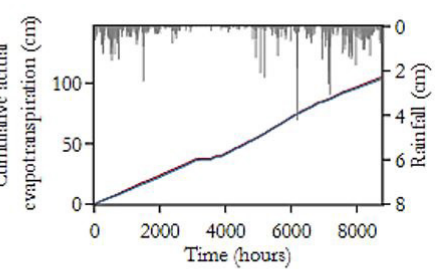

ime (hours)
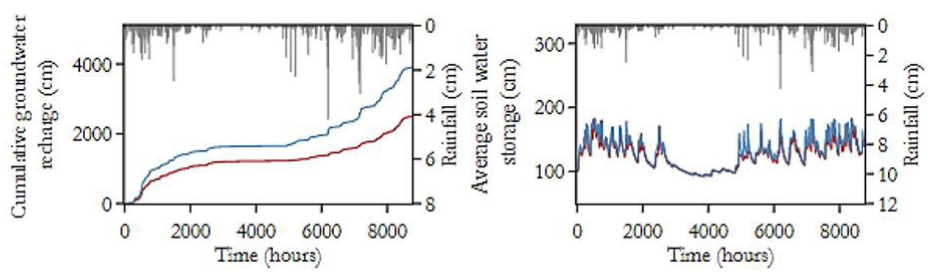

- Hourly Daily

Figure 7. Hourly versus Daily simulation for the variables: (a) cumulative surface runoff; (b) cumulative infiltration; (c) cumulative actual evapotranspiration; (d) cumulative groundwater recharge, and (e) average soil water storage. 
generation of surface runoff. It is also observed that there is an anticipation of the flow initiation processes and a longer flow duration on the hourly scale when compared to the daily scale. Besides, it is noted that the surface runoff generation process is controlled by the intensity of precipitation when hourly data are used. When using daily data, the hypothesis is that the surface runoff generation process is being controlled by the hydrodynamic properties, mainly by the hydraulic conductivity as a function of soil moisture.

For Mertens et al. (2002), when using daily rainfall records as input in a soil water flow model, no information on rainfall intensity is available and the model will be unable to simulate surface runoff because it will distribute the rainfall amount over the 24 hours of the day. Liu \& Chui (2017) state that rainfall intensity generally played a more dominant role in runoff generation than rainfall volume. The authors observed direct correlations between peak runoff and time to runoff initiation. However, for Hou et al. (2008), other factors such as the geometry and composition of the subbase can influence the generation of surface runoff in permeable pavements.

\section{Parameter sensitivity analysis}

Figures 8, 9, 10, 11 and 12 show the dynamics of output variables variation when subjected to changes in the hydrodynamic parameters in hourly resolution. They indicate the cumulative surface runoff, cumulative infiltration, cumulative actual evapotranspiration, average soil water storage, and cumulative groundwater recharge, respectively. Besides, the missing values indicate combinations of parameters where the model did not converge.

The surface runoff showed higher sensitivity to the layer 1 parameters, with saturated hydraulic conductivity being the hydrodynamic property that most influenced the partition of rainfall into infiltration and surface runoff, generating an increase of up to $46 \%$ of the model's estimated surface runoff when reduced by $50 \%$ to Ks. In general, there is an approximately linear relationship between Ks and the surface runoff (Figure 8a). Surface runoff is generated once the soil infiltration capacity is exceeded. A similar result was obtained by Köhne et al. (2011) who also observed a high sensitivity of $\mathrm{Ks}$ in the simulation of runoff and soil water distribution processes using Hydrus-2D. Besides, it is observed that the ' $n$ ' and ' $\alpha$ ' parameters also had an influence, however, the differences observed in the estimated surface runoff were at most $15 \%$.

For layers 2, 3, 4 and 5, it is noted that the magnitude order of the hydrodynamic properties' influence decreases as the layer moves away from the surface. This result was expected, since the surface runoff is mainly controlled by the hydrodynamic properties of the surface, mainly the saturated hydraulic conductivity.

In relation to the other variables, actual evapotranspiration showed low sensitivity to parameter variation. As expected, the hydrodynamic parameters of the coating layer had the most significant influence on this variable. A 50\% reduction in the soil moisture reference value to saturation of the coating layer caused an underestimation of almost $11 \%$ of the model's estimated evapotranspiration. Therefore, this was the most predominant parameter. This result is due to the fact that the soil moisture and saturation influence the amount of water available for a)

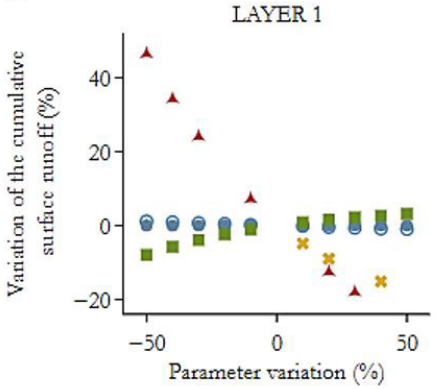

b)

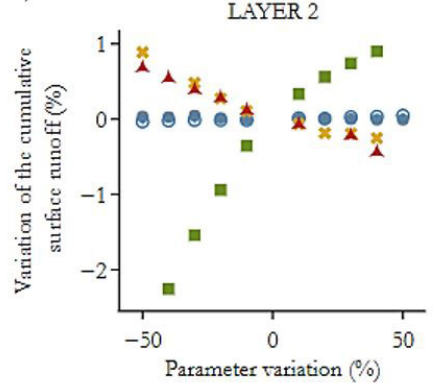

c)

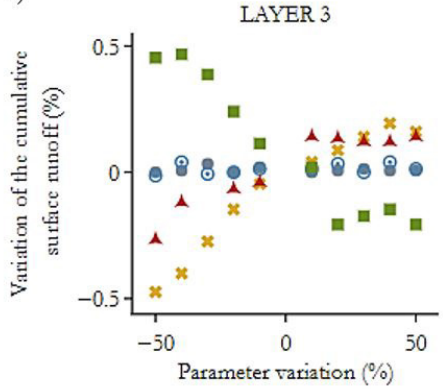

d)

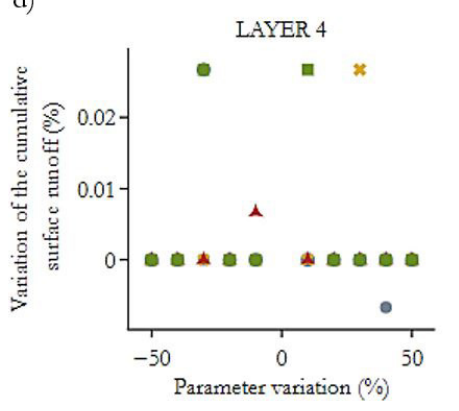

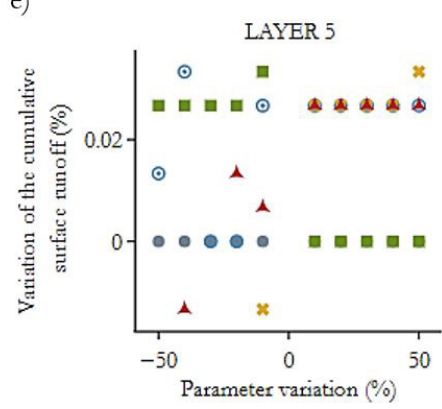

$$
\begin{array}{llllllllll} 
& \theta_{\mathrm{r}} & \odot & \theta_{s} & * & \mathrm{n} & 4 & \mathrm{~K}_{s} & \square & \alpha
\end{array}
$$

Figure 8. The sensitivity of cumulative surface runoff when subjected to variation in the parameters $\theta \mathrm{s}, \theta \mathrm{r}, \alpha$, n, and Ks of layers (a) 1, (b) 2, (c) 3, (d) 4 and (e) 5 . 

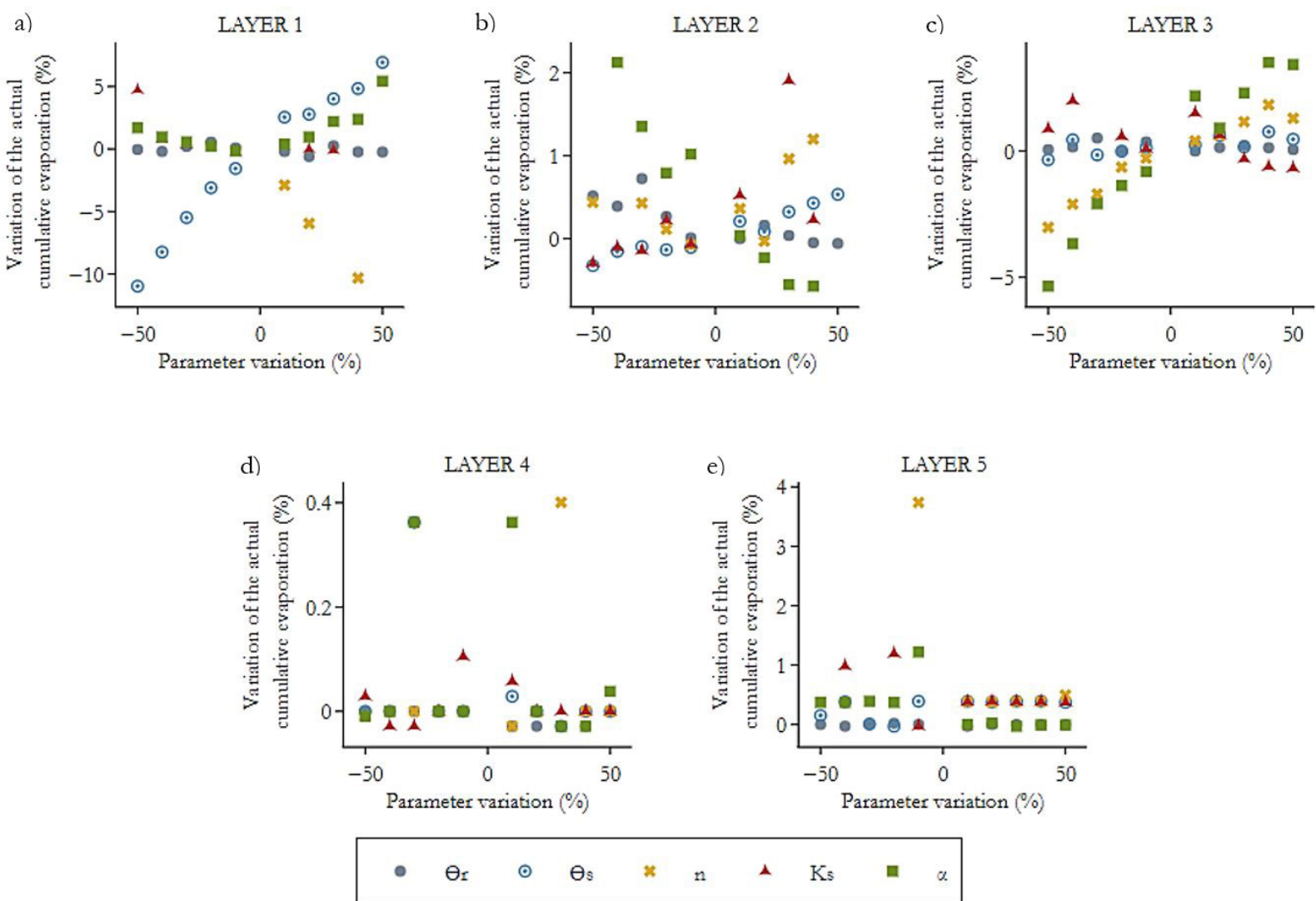

Figure 9. The sensitivity of cumulative actual evapotranspiration when subjected to variation in the parameters $\theta \mathrm{s}, \theta \mathrm{r}, \alpha$, n, and $\mathrm{Ks}$ of layers (a) 1, (b) 2, (c) 3, (d) 4 and (e) 5 .

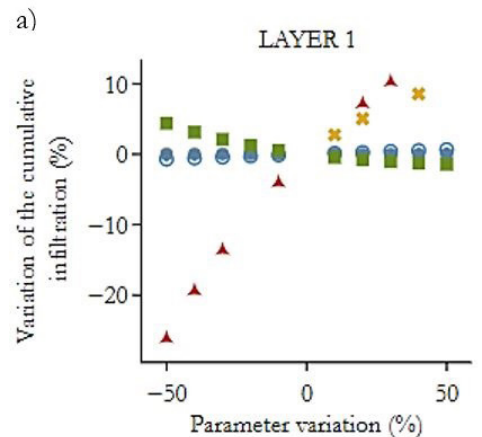

d)

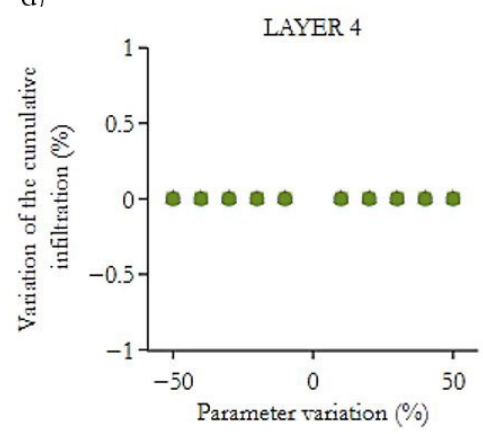

LAYER 2

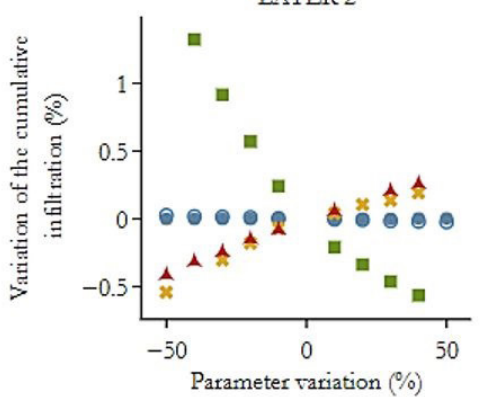

e)

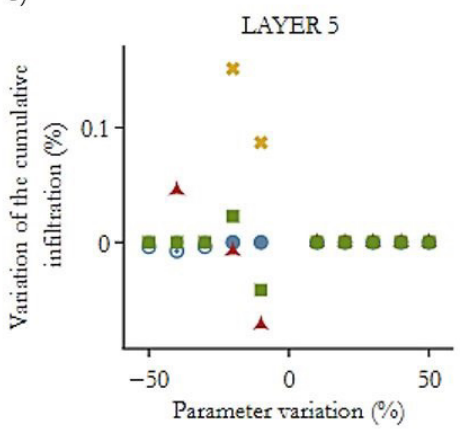

LAYER 3

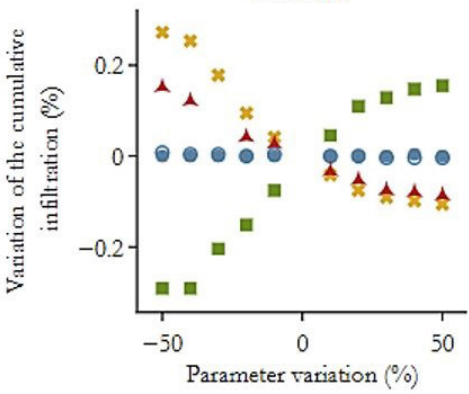

Parameter variation (\%)

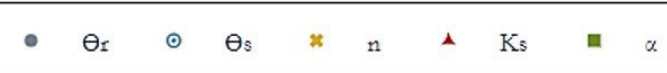

Figure 10. The sensitivity of the cumulative infiltration when subjected to variation in the parameters $\theta$ s, $\theta \mathrm{r}, \alpha, \mathrm{n}$, and Ks of layers (a) 1, (b) 2, (c) 3, (d) 4 and (e) 5 . 
a)

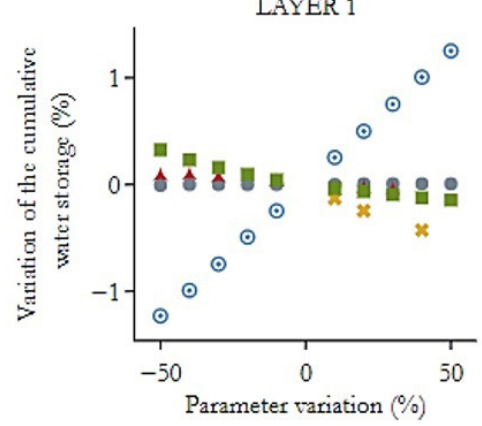

d)

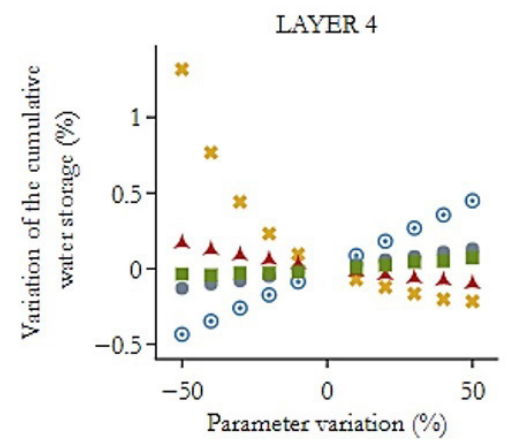

b)

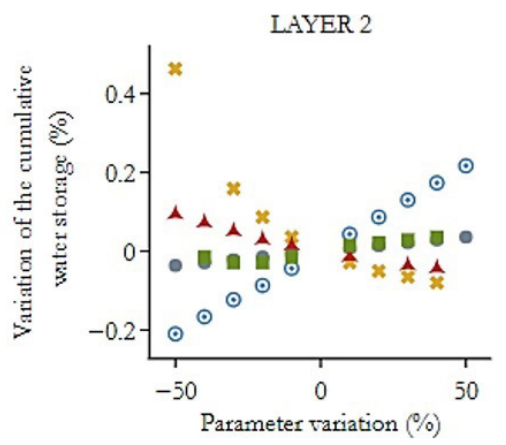

c)

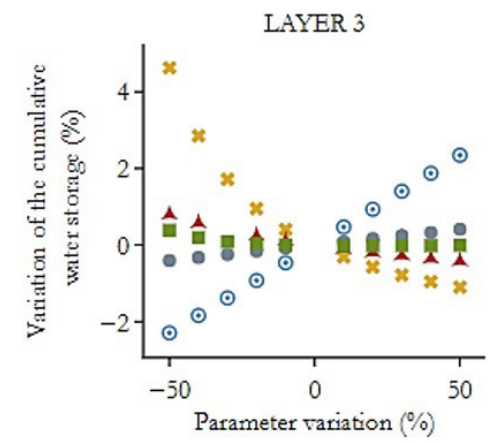

e)

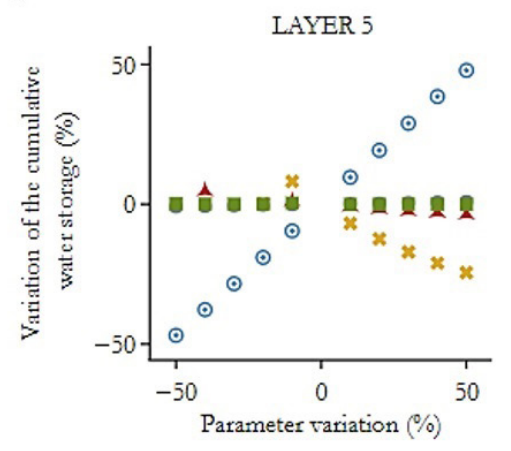

Figure 11. The sensitivity of the cumulative water storage when subjected to variation in the parameters $\theta \mathrm{s}, \theta \mathrm{r}, \alpha, \mathrm{n}$, and Ks of layers (a) 1, (b) 2, (c) 3, (d) 4, and (e) 5 .

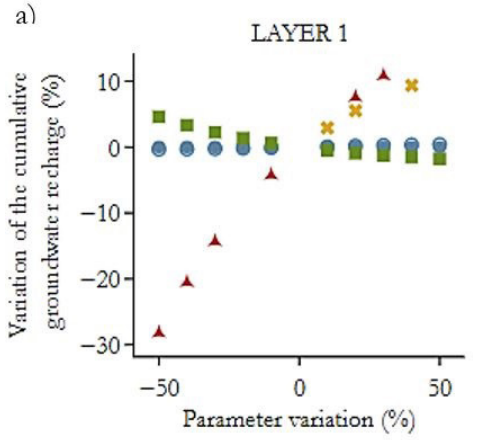

d)

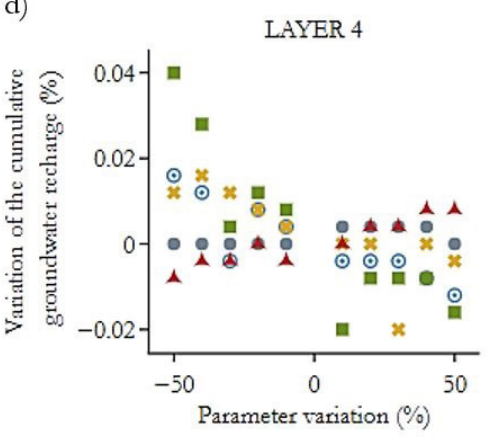

LAYER 2

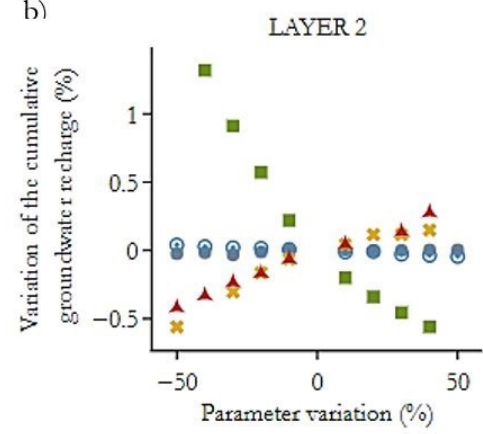

c)

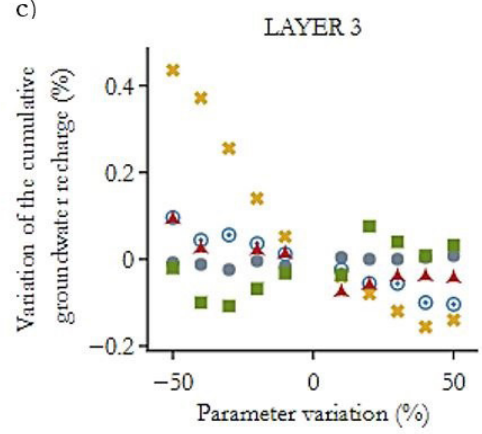

e)

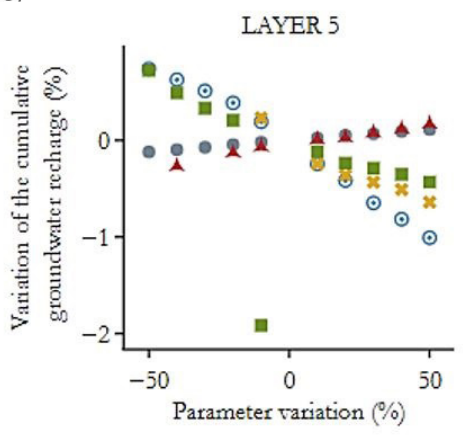

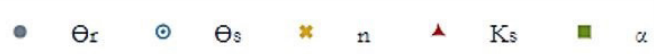

Figure 12. The sensitivity of cumulative groundwater recharge when subjected to variation in the parameters $\theta \mathrm{s}, \theta \mathrm{r}, \alpha$, n, and Ks of layers (a) 1, (b) 2, (c) 3, (d) 4, and (e) 5. 
evapotranspiration in layer 1 . The ' $n$ ' parameter was the second most sensitive, causing an underestimation of slightly more than $10 \%$ when the parameter reference value was increased by $40 \%$ of layer 1 . Besides, the ' $\alpha$ ' parameter altered the estimated evapotranspiration by up to $5.4 \%$ (Figure 9 a). Similar to what was observed for runoff, there is a low influence of the variation in the properties of the other layers in the evapotranspiration process.

Rainfall water infiltrates into the permeable pavement profile at a rate that is equal to the rainfall rate until the soil infiltration capacity is reached. As shown in Figure 10, the cumulative infiltration is insensitive to variation of almost all parameters except for the 'Ks', ' $n$ ' and ' $\alpha$ ' parameters of the coating layer. In general, a 30\% increase in saturated hydraulic conductivity causes an increase of around $10 \%$ in the cumulative infiltration. Also, a $40 \%$ increase in the ' $n$ ' shape parameter contributes to a $10 \%$ increase in the estimated cumulative infiltration.

The water content stored in the permeable pavement profile showed higher sensitivity to the parameters of the last layer of the pavement, particularly to soil moisture at saturation and to the shape parameter ' $n$ '. Variations in the saturated hydraulic conductivity, residual soil moisture, and the normalization parameter $(\alpha)$ caused small disturbances in the simulation result. Also, variations in parameters of the sand layers 2 and 4 had little influence on the change of output variable, being less than $1.5 \%$ for all cases (Figure 11b, d). To layers 1 and 3, the influence on the water storage process is also negligible.

The soil moisture at saturation of the subbase layer presented the highest influence on the estimation of the average water storage, interacting in a linearly and directly proportional way. These results were expected since the stored water depth is proportional to the thickness of the layer. As layer 5 is more prevalent in the simulated cross-section, changes in soil moisture and saturation end up governing the average water storage of the section.

Moreover, it is observed that in all layers, the ' $n$ ' variation is inversely related to the variation of the average water storage, which is natural, because high ' $n$ ' values indicate that the desaturation occurs faster. Consequently, the lower the ' $n$ ' value, the higher the estimation of the cumulative water content.

Cumulative groundwater recharge showed direct relationships with the saturated hydraulic conductivity and the shape parameter ' $n$ ' of the first layer, with ' $\mathrm{Ks}$ ' being the most influential parameter. The recharge value was underestimated by almost $30 \%$ by reducing 'Ks' by $50 \%$. To privilege the infiltration process, the materials must have high saturated hydraulic conductivity and high sorptivity (Bouarafa et al., 2019). This fact underlines the need for maintenance actions of the superficial layer of permeable pavements that can maintain satisfactory levels of infiltration, facilitating the reduction of surface runoff and redistribution of the water in the deeper layers, promoting recharge of aquifers. Although it participates in water redistribution processes, variations in parameters of other layers cause almost negligible perturbations, having a maximum value of $1.9 \%$ (Figure 12b, c, d and e).

The average absolute relative sensitivity values of the Hydrus-1D model for each of the parameters at hourly and daily temporal scales are presented in Figure 13. Considering the effect on all output variables, on average, the most influential parameter is ' $\mathrm{Ks}$ ' for all temporal resolutions. Particularly, the sensitivity of surface runoff to the saturated hydraulic conductivity on the daily time scale was approximately eight times higher than on the hourly time scale (6.018 for daily, 0.755 for hourly). Besides, the surface runoff also showed high sensitivity to shape parameters of the coating layer on the daily resolution (4.018 for ' $\mathrm{n}_{1}$ ' and 0.734 for ' $\alpha_{1}^{\prime}$ ). This allows us to hypothesize that the hydrodynamic parameters have a higher influence than the meteorological variables on the daily resolution. Conversely, an increase in the temporal resolution, causes the surface runoff to be hypothetically controlled by meteorological variables.

The evapotranspiration was sensitive to most of the analyzed parameters. The relative sensitivity indexes of the other output variables to the parameters of layers 2, 3 and 4 were low or null. This shows the low influence of these layers on the water transfer processes in the permeable pavement.

According to the classification presented in Chaves (1991), the model shows low sensitivity or is non-sensitive to all parameters analyzed in the estimation of water infiltration and groundwater recharge. Thus, an experimental determination of these would not significantly increase the accuracy of the adjustment and it could be set at any viable value in the parameter space without affecting the quality of the results obtained in the simulations.

For the average water storage, the model has intermediate sensitivity to the ' $\theta$ ' and ' $n$ ' parameters of the subbase layer and shows low sensitivity or is non- sensitive to other parameters. This behavior is intuitive because the ' $n$ ' parameter also defines the shape of the van Genuchten-Mualem function, and therefore his influence on the retention properties of the material is significant. In the estimation of the actual evapotranspiration, the model has low sensitivity to all hydrodynamic parameters at hourly resolution and high sensitivity at daily resolution. In general, the modeling results are more sensitive to the coating layer parameters, which strongly influence the output variation.

Brunetti et al. (2018), by analyzing the base flow sensitivity simulated by the Hydrus-1D model in a permeable pavement, identified that the shape parameters of the pavement constituent layers presented the most significant influences on the model estimated output. It was also found that the saturated hydraulic conductivities of the coating and base layers were the least sensitive parameters. In another study, Brunetti et al. (2017) performed a sensitivity analysis of the Hydrus model outputs to the soil hydraulic properties of a rainwater filter. Similarly, the shape parameter $(\alpha)$ of the filter layer had a dominant effect on the simulated output stream.

Turco et al. (2017), performing a sensitivity analysis on a porous concrete pavement, found that the saturated hydraulic conductivity of the coating layer had a negligible influence on the simulated water content and a minimal effect on the base flow. The same was observed by Brunetti et al. (2016), when analyzing the sensitivity of hydrodynamic parameters of permeable pavement. At the time, the saturated hydraulic conductivity of the coating layer had a limited direct effect on the baseflow, but significant interaction with other parameters.

Stewart et al. (2017) performed a sensitivity analysis of the Hydrus model to hydrodynamic parameters in a bioretention cell. The saturated hydraulic conductivity and the water retention 


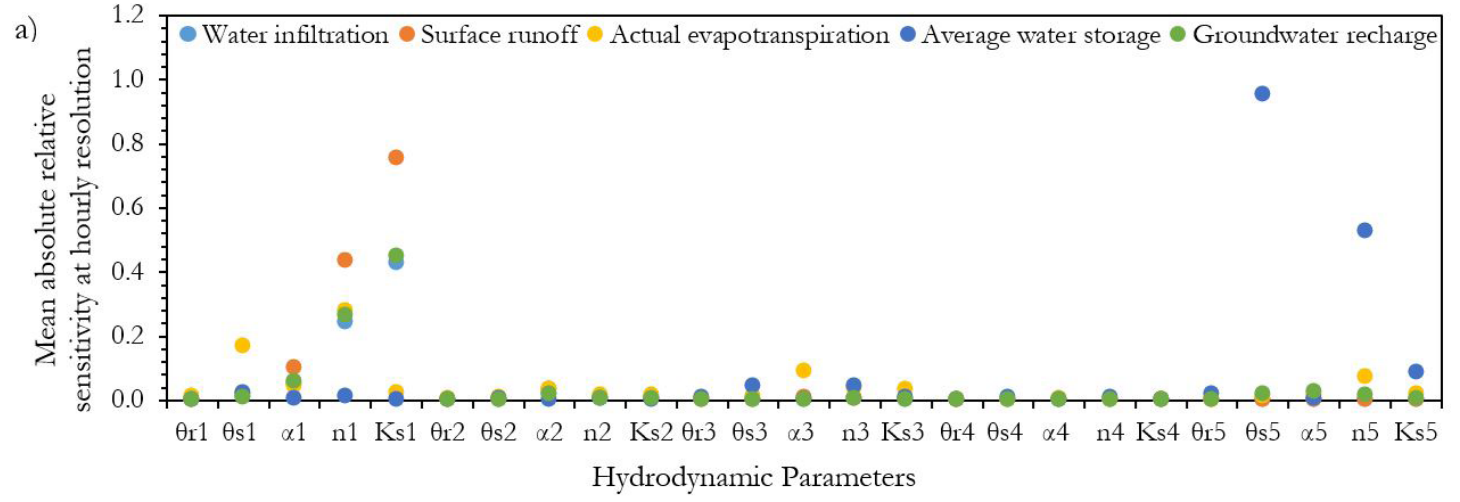

b)

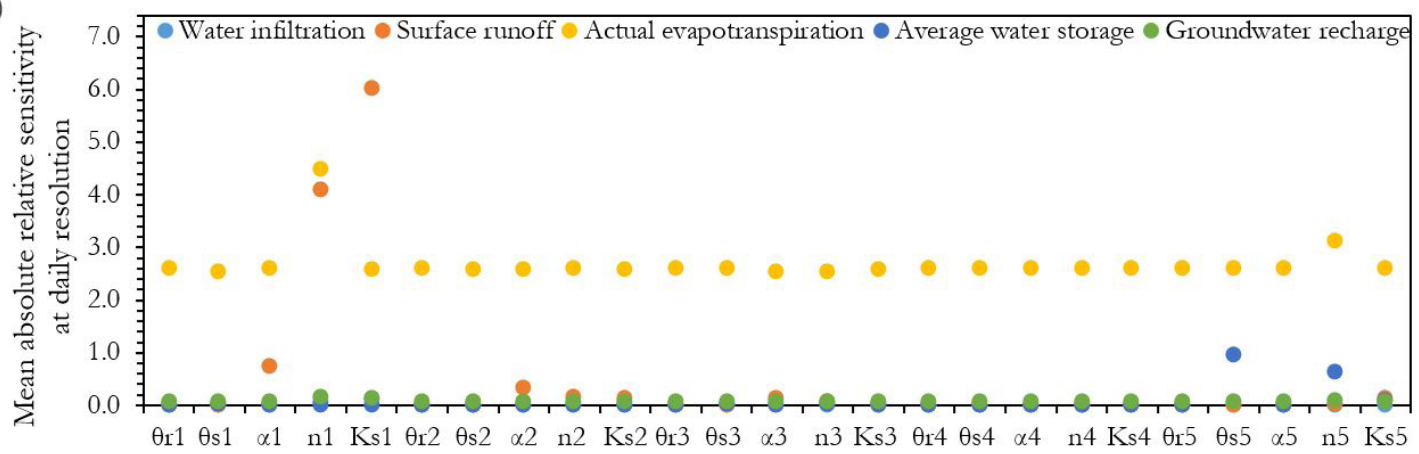

Hydrodynamic Parameters

Figure 13. Relative sensitivity average of output variables to the hydrodynamic parameters at resolutions (a) hourly and (b) daily. The subscribed indices refer to each layer of the permeable pavement.

shape parameter $(\alpha)$ were analyzed for soil layers in and around the bioretention cell. In the study, the overall hydrologic response was regulated by the hydraulics of the cell fill material that controlled the water infiltration into the system and the native soil retention parameters that controlled the connectivity between surface and groundwater.

\section{CONCLUSIONS}

This article presented a sensitivity analyzes of water transfer processes in a permeable pavement. Then, the spatial discretization degree, temporal resolution of meteorological data of boundary condition and the hydrodynamic parameters of several layers of the device structure were evaluated. The Hydrus 1-D model was used to solve Richards' equation for a highly heterogeneous medium.

For the spatial discretization degree, the domain was divided into 101, 201, 301, 401, 501 and 601 elements. The parameters of the retention and conductivity curves were analyzed for the van Genutchen model. From the conducted simulations, the following can be concluded:

The mesh sensitivity analysis showed that spatial discretization did not exert an important influence on the scenarios of the flow variable. The analysis can influence researches that seek to understand water transfer processes in a structure as a permeable pavement through Richards' equation. Overall, less refined meshes require lower computers operating cost, and consequently, speed up simulations.
The use of meteorological input data with different temporal resolutions for the simulation of the water transfer processes in the permeable pavement section demonstrated that the hydrodynamic parameters have a higher influence than the climatic variables in the daily resolution. The use of climatological data with hourly temporal resolution demonstrated that the runoff was hypothetically controlled by the meteorological variables.

The sensitivity analysis of the hydrodynamic parameters showed that the coating layer acted predominantly on surface runoff processes at the permeable pavement. The saturated hydraulic conductivity was the most influential hydrodynamic property in the processes of the partition of the rainfall in surface runoff and infiltrated blade. The soil moisture at saturation ' $\theta$ ' ' and the shape parameter of the retention curve ' $n$ ' of the subbase layer strongly influenced the magnitude of water content stored in the profile. An accurate experimental determination of these parameters would significantly increase the accuracy of the adjustment for these output variables in the permeable pavement when calibrating and validating the model.

\section{ACKNOWLEDGEMENTS}

The authors acknowledge the support of FACEPE for the M.Sc scholarship of the first author and the CNPq for the PQ grants of the third and seventh authors. This work also was carried out with support of the project "Transfer of Water and 
Mixtures of Reactive Pollutants in Anthropized Soils" (CNPq process $n^{\circ}$. 436875/2018-7).

\section{REFERENCES}

Allen, R. G., Pereira, L. S., Raes, D., \& Smith, M. (1998). Crop evapotranspiration: guidelines for computing crop water requirements (FAO Irrigation and Drainage Paper, No. 56, pp. e156). Rome: FAO.

Alves, E. M., Maciel Netto, A., \& Antonino, A. C. D. (2012). Simulação da dinâmica da água em solo cultivado com Feijão Caupi no Brejo Paraibano. Revista Brasileira de Recursos Hídricos, 17(3), 175-186. http:/ / dx.doi.org/10.21168/rbrh.v17n3.p175-186.

Bouarafa, S., Lassabatere, L., Lipeme-Kouyi, G., \& Angulo-Jaramillo, R. (2019). Hydrodynamic characterization of Sustainable Urban Drainage Systems (SuDS) by using Beerkan infiltration experiments. Water, 11(4), 660. http://dx.doi.org/10.3390/w11040660.

Braswell, A. S., Winston, R. J., \& Hunt, W. F. (2018). Hydrologic and water quality performance of permeable pavement with internal water storage over a clay soil in Durham, North Carolina. Journal of Environmental Management, 224, 277-287. PMid:30055460. http:/ / dx.doi.org/10.1016/j.jenvman.2018.07.040.

Braud, I., De Condappa, D., Soria Uglade, J. M., Haverkamp, R., Angulo-Jaramillo, R., Galle, S., \& Vauclin, M. (2005). Use of scaled forms of the infiltration equation for the estimation of unsaturated soil hydraulic properties (the Beerkan method). European Journal of Soil Science, 56(3), 361-374. http://dx.doi.org/10.1111/j.13652389.2004.00660.x.

Brunetti, G., Šimůnek, J., \& Piro, P. (2016). A comprehensive numerical analysis of the hydraulic behavior of a permeable pavement. Journal of Hydrology, 540, 1146-1161. http://dx.doi.org/10.1016/j. jhydrol.2016.07.030.

Brunetti, G., Simunek, J., Turco, M., \& Piro, P. (2017). On the use of surrogate-based modeling for the numerical analysis of Low Impact Development techniques. Journal of Hydrology, 548, 263-277. http:// dx.doi.org/10.1016/j.jhydrol.2017.03.013.

Brunetti, G., Šimůnek, J., Turco, M., \& Piro, P. (2018). On the use of global sensitivity analysis for the numerical analysis of permeable pavements. Urban Water Journal, 15(3), 269-275. http://dx.doi.org/1 0.1080/1573062X.2018.1439975.

Bruno, L. O., Amorim, R. S. S., \& Silveira, A. (2013). Estudo da redução do escoamento superficial direto em superfícies permeáveis. Revista Brasileira de Recursos Hídricos, 18(2), 237-247. http://dx.doi. org/10.21168/rbrh.v18n2.p237-247.

Burdine, N. (1953). Relative permeability calculations from pore size distribution data. Journal of Petroleum Technology, 5(3), 71-78. http:// dx.doi.org/10.2118/225-G.
Carsel, R. F., \& Parrish, R. S. (1988). Developing joint probability distributions of soil water retention characteristics. Water Resources Research, 24(5), 755-769. http://dx.doi.org/10.1029/WR024i005p00755.

Chaves, H. M. L. (1991). Análise global de sensibilidade dos parâmetros da equaçáo universal de perda de solo modificada (muscle) (Global sensitivity analysis of the parameters of the universal modified soil loss equation (muscle)). Revista Brasileira de Ciência do Solo, 15(3), 345-350.

Coutinho, A. P. (2011). Pavimento permeável como técnica compensatória na drenagem urbana da cidade do Recife (Dissertação de mestrado). Universidade Federal de Pernambuco, Recife.

Coutinho, A. P., Lassabatere, L., Montenegro, S., Antonino, A. C. D., Angulo-Jaramillo, R., \& Cabral, J. J. (2016). Hydraulic characterization and hydrological behaviour of a pilot permeable pavement in urban centre, Brazil. Hydrological Processes, 30, 4242-4254. http://dx.doi. org/10.1002/hyp.10985.

Coutinho, A. P., Lassabatere, L., Winiarski, T., Cabral, J., Antonino, A., \& Angulo-Jaramillo, R. (2015). Vadose zone heterogeneity effect on unsaturated water flow modeling at meso-scale. Journal of Water Resource and Protection, 7(04), 353-368. http://dx.doi.org/10.4236/ jwarp.2015.74028.

Eckart, K., McPhee, Z., \& Bolisetti, T. (2017). Performance and implementation of low impact development: a review. The Science of the Total Environment, 607-608, 413-432. PMid:28704668. http:// dx.doi.org/10.1016/j.scitotenv.2017.06.254.

Gabiri, G., Burghof, S., Diekkrüger, B., Leemhuis, C., Steinbach, S., \& Näschen, K. (2018). Modeling spatial soil water dynamics in a tropical floodplain, East Africa. Water, 10(2), 191. http://dx.doi. org/10.3390/w10020191.

Graciosa, M. C. P., Mendiondo, E. M., \& Chaudhry, F. H. (2008). Simulação hidráulica de trincheiras de infiltração de águas pluviais. Revista Brasileira de Recursos Hídricos, 13(2), 89-99. http://dx.doi. org/10.21168/rbrh.v13n2.p89-99.

Hou, L., Feng, S., Huo, Z., Ding, Y., \& Zhang, S. (2008). Experimental study on rainfall-runoff relation for porous pavements. Hydrology Research, 39(3), 181-190. http://dx.doi.org/10.2166/nh.2008.001.

Instituto Nacional de Meteorologia - INMET. (2020). Retrieved in 2019, December 21, from http://www.inmet.gov.br/portal/index. php?r=bdmep/bdmep

Jabur, A. S., Dornelles, F., Silveira, A. L. L., Goldenfum, J. A., Okawa, C. M. P., \& Gasparini, R. L. (2015). Determination of the infiltration capacity of permeable pavements. Revista Brasileira de Recursos Hidricos, 20(4), 937-945. http://dx.doi.org/10.21168/rbrh.v20n4.p937-945.

Kamali, M., Delkash, M., \& Tajrishy, M. (2017). Evaluation of permeable pavement responses to urban surface runoff. Journal of EnvironmentalManagement, 187, 43-53. PMid:27875770. http://dx.doi. org/10.1016/j.jenvman.2016.11.027. 
Köhne, J. M., Wöhling, T., Pot, V., Benoit, P., Leguédois, S., Le Bissonnais, Y., \& Šimůnek, J. (2011). Coupled simulation of surface runoff and soil water flow using multi-objective parameter estimation. Journal of Hydrology, 403(1-2), 141-156. http://dx.doi.org/10.1016/j. jhydrol.2011.04.001.

Lassabatère, L., Angulo-Jaramillo, R., Soria Ugalde, J. M., Cuenca, R., Braud, I., \& Haverkamp, R. (2006). Beerkan Estimation of Soil Transfer parameters through infiltration experiments - BEST. Soil Science Society of America Journal, 70(2), 521-532. http://dx.doi. org/10.2136/sssaj2005.0026.

Liu, C. Y., \& Chui, T. F. M. (2017). Factors influencing stormwater mitigation in permeable pavement. Water, 9(12), 988.

Liu, J., Yan, H., Liao, Z., Zhang, K., Schmidt, A. R., \& Tao, T. (2019). Laboratory analysis on the surface runoff pollution reduction performance of permeable pavements. The Science of the Total Environment, 691, 1-8. PMid:31306873. http://dx.doi.org/10.1016/j.scitotenv.2019.07.028.

McCuen, R. H., \& Snyder, W. M. (1986). Hydrologic modeling: statistical methods and applications. New York: Prentice-Hall.

Melo, T. A. T., Coutinho, A. P., Santos, J. B. F., Cabral, J. J. S. P., Antonino, A. C. D., \& Lassabatere, L. (2016). Trincheira de infiltração como técnica compensatória no manejo das águas pluviais urbanas (Infiltration trench as compensatory technique in urban stormwater management). Ambiente Construido, 16(3), 53-72. http://dx.doi. org/10.1590/s1678-86212016000300092.

Mertens, J., Raes, D., \& Feyen, J. (2002). Incorporating rainfall intensity into daily rainfall records for simulating runoff and infiltration into soil profiles. Hydrological Processes, 16(3), 731-739. http://dx.doi. org/10.1002/hyp.1005.

Mualem, Y. (1976). A new model for predicting the hydraulic conductivity of unsaturated porous media. Water Resources Research, 12(3), 513-522. http://dx.doi.org/10.1029/WR012i003p00513.

Oleson, K. W., Monaghan, A., Wilhelmi, O., Barlage, M., Brunsell, N., Feddema, J., Hu, L., \& Steinhoff, D. F. (2015). Interactions between urbanization, heat stress, and climate change. Climatic Change, 129(3-4), 525-541. http://dx.doi.org/10.1007/s10584-013-0936-8.

Richards, L. A. (1931). Capillary conduction of liquids through porous mediums. Physics, 1(5), 318-333. http://dx.doi.org/10.1063/1.1745010.

Silva Ursulino, B., Montenegro, S. M. G. L., Coutinho, A. P., Coelho, V. H. R., Araújo, D. C. S., Gusmão, A. C. V., \& Angulo-Jaramillo, R. (2019). Modelling soil water dynamics from soil hydraulic parameters estimated by an alternative method in a tropical experimental basin. Water, 11(5), 1007. http://dx.doi.org/10.3390/w11051007.

Šimůnek, J., \& Van Genuchten, M. Th. (2008). Modeling nonequilibrium flow and transport processes using HYDRUS. Vadose Zone Journal, 7(2), 782-797. http://dx.doi.org/10.2136/vzj2007.0074.
Stewart, R. D., Lee, J. G., Shuster, W. D., \& Darner, R. A. (2017). Modelling hydrological response to a fully-monitored urban bioretention cell. Hydrological Processes, 31(26), 4626-4638. http:// dx.doi.org/10.1002/hyp.11386.

St-Hilaire, A., Duchesne, S., \& Rousseau, A. N. (2016). Floods and water quality in Canada: a review of the interactions with urbanization, agriculture and forestry. Canadian Water Resources Journal, 41(1-2), 273287. http://dx.doi.org/10.1080/07011784.2015.1010181.

Tarqui, J. L. Z., Carvalho, M. D. F., Santos, C. M. L. D., \& Santos, J. E. D. (2019). Avaliação do escoamento superficial de águas pluviais em pavimento de blocos de solo-cimento. Engenharia Sanitaria e Ambiental, 24(2), 403-410. http://dx.doi.org/10.1590/s1413-41522019153148.

Turco, M., Kodešová, R., Brunetti, G., Nikodem, A., Fér, M., \& Piro, P. (2017). Unsaturated hydraulic behaviour of a permeable pavement: laboratory investigation and numerical analysis by using the HYDRUS-2D model. Journal of Hydrology, 554, 780-791. http:// dx.doi.org/10.1016/j.jhydrol.2017.10.005.

Van Genuchten, M. Th. (1980). A closed-form equation for predicting the hydraulic conductivity of unsaturated soils 1 . Soil Science Society of America Journal, 44(5), 892-898. http://dx.doi.org/10.2136/sssaj198 $0.03615995004400050002 x$.

Van Genuchten, M. T., Leij, F. J., \& Yates, S. R. (1991). The RETC code for quantifying the bydraulic functions of unsaturated soils. Ada, OK: U.S. Environmental Protection Agency.

\section{Authors contributions}

Ialy Rayane de Aguiar Costa: Manuscript structure, literature review, methods, analysis and discussion of the results.

Artur Paiva Coutinho: Study orientation, literature review and methods.

Suzana Maria Gico Lima Montenegro: Study orientation, literature review and methods.

Ana Emília Carvalho de Gusmão da Cunha Rabelo: Analysis of the results and discussion.

Severino Martins dos Santos Neto: Analysis of the results from Hydrus model and technical review of the manuscript.

Edevaldo Miguel Alves: Analysis of the results from Hydrus model and technical review of the manuscript.

Antonio Celso Dantas Antonino: Study orientation, literature review and methods. 